\title{
Weight Changes in Wild Wolves, Canis lupus, from Ages 2 to 24 Months
}

\author{
L. DAVID MECH ${ }^{1,2}$
}

${ }^{1}$ U.S. Geological Survey, Northern Prairie Wildlife Research Center, $8711-37^{\text {th }}$ Street SE, Jamestown, North Dakota 58401-7317 USA

${ }^{2}$ Mailing address: The Raptor Center, 1920 Fitch Avenue, University of Minnesota, St. Paul, Minnesota 55108 USA

Mech, L. David 2008. Weight changes in wild Wolves (Canis lupus) from ages 2 to 24 months. Canadian Field Naturalist 122(2): 173-175

Weights of 118 female and 141 male Minnesota Wolves (Canis lupus) aged 2-24 months increased almost linearly from about $8 \mathrm{~kg}$ for females and $10 \mathrm{~kg}$ for males at 3 months to $30 \mathrm{~kg}$ for females and $32 \mathrm{~kg}$ for males at $10-12$ months and then tended to increase much more slowly in an overall curvilinear trend. Considerable variation was apparent for both sexes during their first year.

Key Words: Wolves, Canis lupus, weights, growth, development, Minnesota.

Weight changes in free-ranging Wolves (Canis lupus) from 3 to 7 months of age have been documented (Van Ballenberghe and Mech 1975), as well as annual changes from 1 to 12 years (Mech 2006). However, weight changes between 7 months and 24 months have not yet been described for wild or captive Wolves. Thus information about the growth and development of wild Wolves remains incomplete. Herein I present information that helps fill that gap.

The study area encompassed some $2060 \mathrm{~km}^{2}$ immediately east of Ely in the east-central Superior National Forest $\left(48^{\circ} \mathrm{N}, 92^{\circ} \mathrm{W}\right)$ of northeastern Minnesota. Winter temperatures below $-35^{\circ} \mathrm{C}$ are not unusual, and snow depths (usually from about mid-November through mid-April) generally ranged from 50 to $75 \mathrm{~cm}$. Temperatures in summer rarely exceeded $35^{\circ} \mathrm{C}$. Conifers predominate in the forest overstory interspersed with large stands of Paper Birch (Betula papyrifera) and Trembling Aspen (Populus tremuloides). Detailed descriptions of the forest vegetation were presented by Ohmann and Ream (1969).

Wolves in the study area feed primarily on Whitetailed Deer (Odocoileus virginianus), Moose (Alces alces), and Beavers (Castor canadensis: Frenzel 1974). The Wolves have been legally protected since 1974 , although some have been killed accidentally or illegally by humans (Mech 1977). The Wolf population in the study area has remained relatively stable since about 1975, after dropping following a major deer decline (Mech 2000:23). The study population has long been saturated and in the late 1970s, canine parvovirus infected the population, resulting in a strong decrease in young pup survival ever since (Mech et al. 2008)

The taxonomic identity of the Wolves in this study is uncertain. Nowak (1995) considered them Canis lupus nubilus based on skull morphology. However, the population includes animals with the same mitochondrial DNA haplotypes as some Wolves in Alaska and western Canada, as well as animals with Coyote (Canis latrans)-like haplotypes also found in eastern Ontario (Lehman et al. 1991). Nevertheless no morphological differences between Wolves of these two mitochondrial DNA haplotypes have been recognized, and both types inhabit the same packs (Lehman et al. 1992). Wilson et al. (2000) suggested that Minnesota Wolves may be assignable to a newly postulated species, Canis lycaon. A less powerful genetic test was consistent with the population being Canis lupus or hybrids between Canis lycaon and Canis lupus (Mech and Federoff 2002).

Most of the Wolves I studied were live-trapped in modified, steel foot traps (Mech 1974) from about 16 Wolf packs throughout the study area from June through December 1970 through 2006. The Wolves were anesthetized and weighed on a spring scale, (Chatillon 160, Largo, Florida, until 1999; and Salter ABS, Santee, California, since then). Pups were distinguished by their milk teeth or newly erupted adult canines (Van Ballenberghe and Mech 1975). Two male and two female pups were then outfitted with capture collars (Mech and Gese 1992), anesthetized remotely, and weighed 6-11 times more through ages 23 months for females and 19 months for males. Contrary to animals captured in live-traps, those captured by capture collars sometimes have food in their stomachs. I estimated the amounts by observing the degree to which the stomachs were distended and subtracted those estimates from the total weights.

Weights were obtained from 152 captures of $118 \mathrm{fe}$ males and from 176 captures of 141 males. Weights of both sexes increased almost linearly from about $8 \mathrm{~kg}$ for females and $10 \mathrm{~kg}$ for males at 3 months to $30 \mathrm{~kg}$ for females and $32 \mathrm{~kg}$ for males at 10-12 months and then tended to level off and increase more slowly (Figure 1). Considerable variation was apparent for both sexes during their first year. This variation is no doubt due to variation in amount of food available as well as to competition within litters for the available food. In addition, some pups with low weight might not have survived long enough to contribute data as older pups.

These results agree with Kuyt (1972) for captive Wolves 1-3 months old and those of Pulliainen (1965, cited in Mech 1970: 124) for single captive Wolves 
Figure 1A.

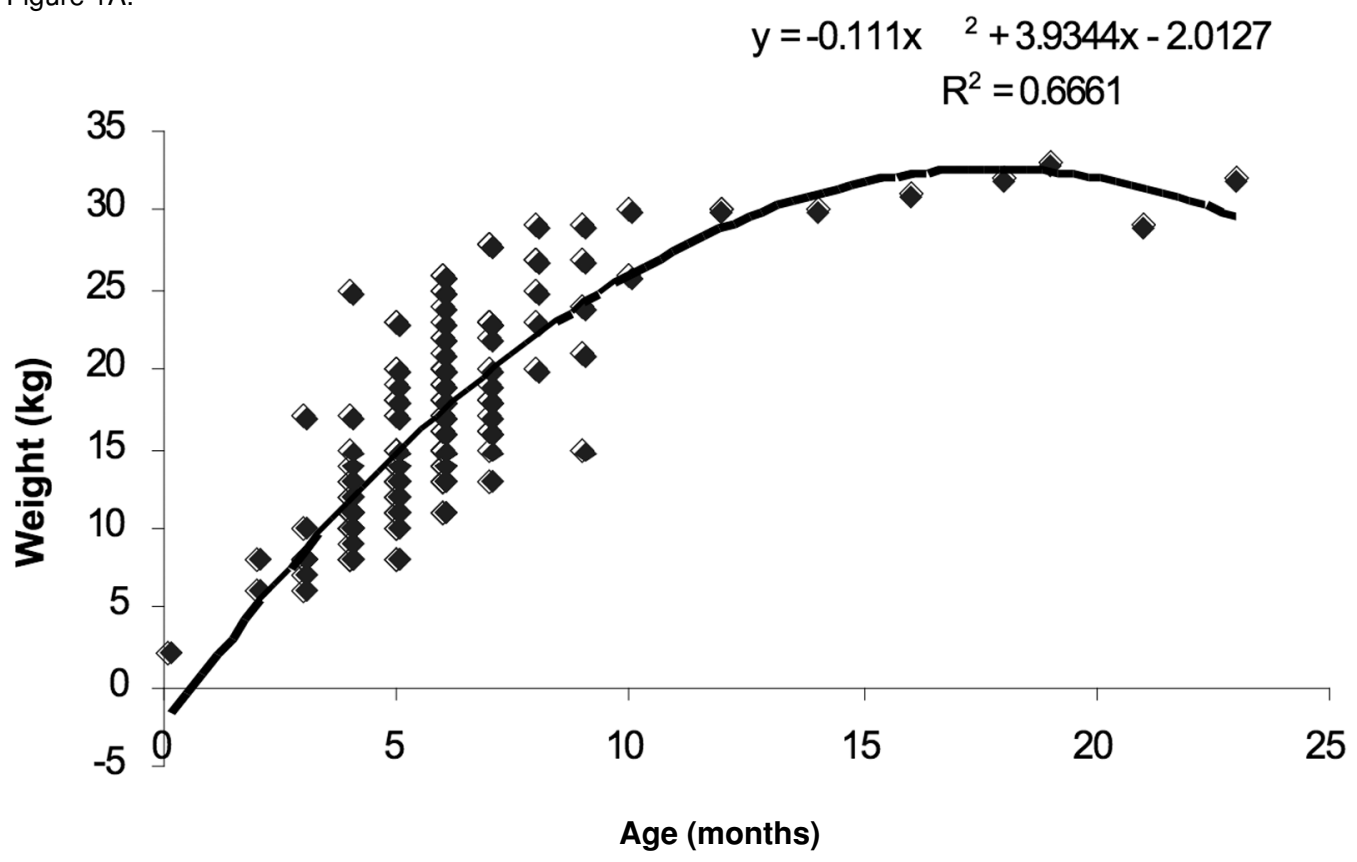

Figure 1B.

$$
\begin{gathered}
y=-0.1183 x \quad{ }^{2}+4.5644 x-4.0274 \\
R^{2}=0.5508
\end{gathered}
$$

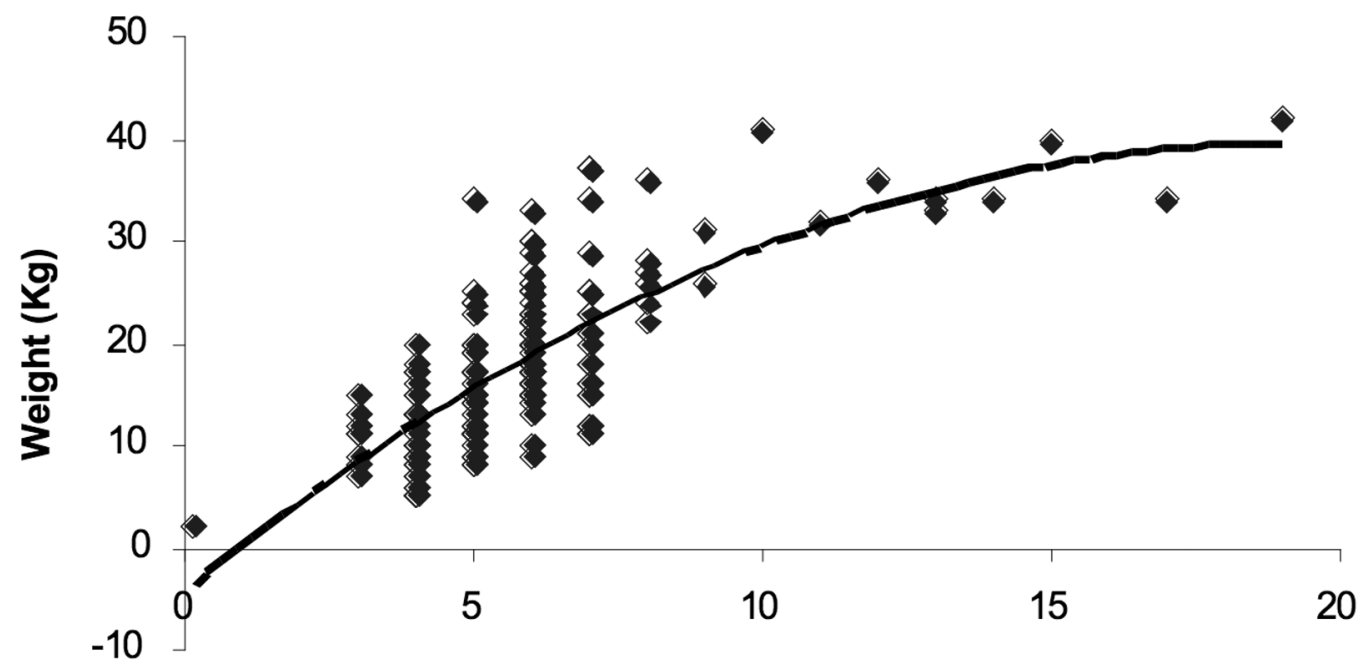

Age (months)

FIGURE 1. Weight changes in Wolves from the Superior National Forest in northeastern Minnesota, 1970-2006. A. females 2-23 months old (1970-2004). B. males 3-19 months-old, (1970-2006). (Assumed $0.5 \mathrm{~kg}$ birth weight to complete trend line [Rutter and Pimlott 1968].) 
from 3 to 7 months. However growth of Pulliainen's (1965) Finnish captives began leveling off at 7 months (female) and 11.5 months (male) rather than at about 12 months for both sexes of Minnesota wild Wolves. It is not clear whether the difference in age of growth leveling off is due to different races of Wolves or better nutrition of captive Wolves.

This study helps complete general information about the weight changes of wild Wolves from about 3 months of age to 12 years of age (Mech 2006). Overall, the pattern of weight gain in wolves within the first two years of age followed a curvilinear relationship. However, more data are still needed for both male and female Wolves 5-12 years old.

\section{Acknowledgments}

This study was supported by the Biological Resources Division, U.S. Geological Survey and the U.S. Department of Agriculture North Central Research Station. M. E. Nelson and numerous volunteers livetrapped the study animals and performed the age estimates. Shannon Barber-Meyer and Dan Stark and two anonymous reviewers offered helpful suggestions for improving the manuscript.

\section{Literature Cited}

Frenzel, L. D. 1974. Occurrence of moose in food of wolves as revealed by scat analyses: A review of North American studies. Le Naturaliste canadien 101: 467-479.

Kuyt, E. 1972. Food habits and ecology of wolves on barren-ground caribou range in the Northwest Territories. Canadian Wildlife Service Report Series 21. 36 pages.

Lehman, N., A. Eisenhawer, K. Hansen, L. D. Mech, R. O. Peterson, P. J. P. Gogan, and R. K. Wayne. 1991. Introgression of coyote mitochondrial DNA into sympatric North American gray wolf populations. Evolution 45: 104 119.

Lehman, N., P. Clarkson, L. D. Mech, T. J. Meier, and R. K. Wayne. 1992. A study of the genetic relationships within and among wolf packs using DNA fingerprinting and mitochondrial DNA. Behavior, Ecology, and Sociobiology 30: 83-94.

Mech, L. D. 1970. The wolf: The ecology and behavior of an endangered species. Natural History Press, Garden City, New York. 389 pages
Mech, L. D. 1974. Current techniques in the study of elusive wilderness carnivores. Pages 315-322 in Proceedings of the $11^{\text {th }}$ International Congress of Game Biologists.

Mech, L. D. 1977. Productivity, mortality and population trends of wolves in northeastern Minnesota. Journal of Mammalogy 58: 559-574.

Mech, L. D. 2000. The wolves of Minnesota: howl in the heartland. Voyageur Press, Stillwater, Minnesota. 128 pages.

Mech, L. D. 2006. Age-related body mass and reproductive measurements of gray wolves in Minnesota. Journal of Mammalogy 87: 80-84

Mech, L. D., and N. E. Federoff. 2002. Alpha ${ }_{1}$-antitrypsin polymorphism and systematics of eastern North American wolves. Canadian Journal of Zoology 80: 961-963.

Mech, L. D., and E. M. Gese. 1992. Field testing of Wildlink Captive Collor on wolves. Wildlife Society Bulletin 20: $240-256$.

Mech, L. D., S. M. Goyal, W. J. Paul, and W. E. Newton. 2008. Demographic effects of canine parvovirus on a freeranging wolf population over 30 years. Journal of Wildlife Diseases 44: 824-836.

Nowak, R. M. 1995. Another look at wolf taxonomy. Pages 375-398 in Ecology and conservation of wolves in a changing world. Edited by L. N. Carbyn, S. H. Fritts and D. R. Seip. Canadian Circumpolar Institute, Occasional Publication Number 35, University of Alberta, Edmonton, Alberta, Canada.

Ohmann, L. F., and R. R. Ream. 1969. Vegetation studies in the BWCA - brief report on plant communities. Naturalist 20: 29-29.

Pulliainen, E. 1965. Studies on the wolf (Canis lupus L.) in Finland. Annales Zoologici Fennici 2: 215-259.

Rutter, R. J., and D. H. Pimlott. 1968. The world of the wolf. J. B. Lippincott Company, Philadelphia, Pennsylvania. 202 pages.

Van Ballenberghe, V., and L. D. Mech. 1975. Weights, growth, and survival of timber wolf pups in Minnesota. Journal of Mammalogy 56: 44-63.

Wilson, P. J., S. Grewal, I. D. Lawford, J. N. M. Heal, A. G. Granacki, D. Pennock, J. B. Theberge, M. T. Theberge, D. R. Voigt, W. Waddell, R. E. Chambers, P. C. Paquet, G. Goulet, D. Cluff, and B. N. White. 2000. DNA profiles of the eastern Canadian wolf and the red wolf provide evidence for a common evolutionary history independent of the gray wolf. Canadian Journal of Zoology 78: 2156-2166.

Received 29 February 2008

Accepted 27 February 2009 